\title{
THE PSALIS \\ FOR THE CONSECRATION OF THE CHURCH (REVISITED)
}

\section{The manuscript}

The description of the manuscript according to the Catalogue of Mingana is as follows:

$239 \times 164 \mathrm{~mm}$. 259 leaves. Nineteen lines to the page. The ritual of the Consecration of a new church and a new altar, according to the ritual of the Coptic Church. The MS is divided into two columns, the first of which is in Coptic and the second in Arabic, as is usual in the MSS. Written after the Arab invasion.

A. Ff. 4a-201: The ritual of the Consecration of a church

B. Ff. 204-255b The ritual of the Consecration of the Altar

Ff. 256a-257b contain a long colophon in which we are informed that the MS was written by the priest-monk in the monastery of St. George of Tūrā on Thursday, the $5^{\text {th }}$ of the month of Hatūr, in the year 1024 of the Martyrs (AD 1308) in the time of John (spelt Yowannes), the Coptic patriarch of Alexandria. ${ }^{1}$

On fol. 203a is an inscription in Arabic by the Coptic Patriarch Cyril, ${ }^{2}$ presenting the Ms. to John, bishop of Salisbury, on the $4^{\text {th }}$ of the month of Bābah, of the year 1615 of the Martyrs (A.D. 1899). Below the inscription is the seal of the Patriarch, dated 1613, probably of the Martyrs (A.D. 1897). On the opposite page (fol. 202b) a similar statement is found in English.

On fol. 8a is a not very clear note in which it is stated that the Ms came to the possession of a spiritual son of the above-mentioned Patriarch John (spelt Yowannes), who was also called John (spelt Yūhanna).

On fol. 255b s an inscription by the son of the last John, who was called Farj-Allah, who gave the Ms. was wakf to a man whose name has been partly obliterated and cannot be deciphered with safety.

(1) See below.

(2) Cyril V (1874-1927AD) is meant, cf. M. Shoukri, Cyril V, in: A. S. AтrYA (ed.), Coptic Encyclopedia, vol. 3 (New York: MacMilan, 1991) 679 
Fol. $3 \mathrm{~b}$ is occupied with a reprensentation of the Cross in black, yellow and red, and on the margins of many leaves is a representation of a bird holding a flower or a fruit in its beak. Many geometrical patterns are also found before the main divisions of the work. The pattern on fol. $203 \mathrm{~b}$ fills the whole page.

The Coptic part of the Ms is written in a bold and clear hand, and the Arabic part in a handsome Egyptian Naskhi. Headings in red. The first Coptic words of a new section are in thick black characters.

The rubrics, unlike those found in MS. 24 [9] (which is only in Arabic) are in both Coptic and Arabic. [Mingana Chr. Arab. 61.] [Coptic-Arabic 2.]

We give here in full the colophon

geN фPAN MфIOT NEM ПШ)H

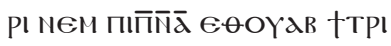

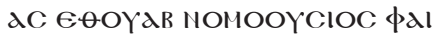

пе пеNMOY' dNON gan NIXPHC

TIANOC

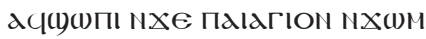

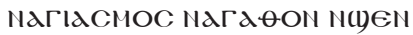

ЕРфмєүІ євод н2Ітотчм

ПIдГIOTATOC NIOT ПI

MAnECWOY ETEN2OT

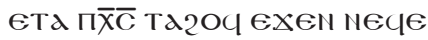

CWOY ETTOYвHOYT фHE

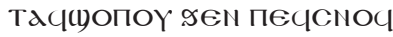

єттаннот єөрєсамонা м

MwOY gen OYMd EqKenIOYWT

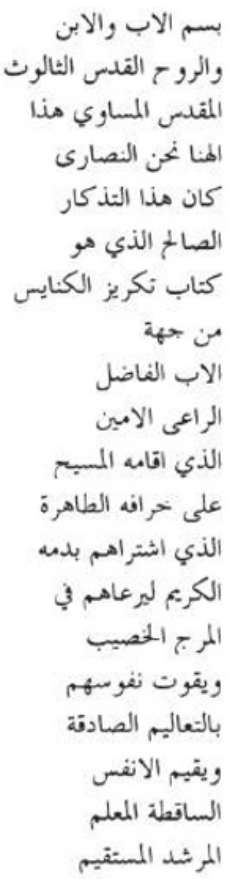

OYO2 E(DANOY(D) TOY YYXH

gen zanсвш OүI EYEn2OT

OYO2 ETA2O nNIYYXH ET

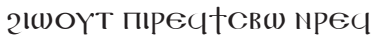

бІмшіт пірецCWOYTEN

Fol. 253v

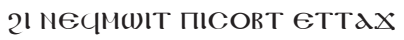

phoYT фheтtenno nNH

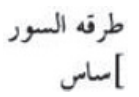

(3) A. Mingana, Catalogue of the Mingana Collection of Manuscripts now in the possession of the trustees of the Woodbrooke settlement, Selly Oak, Birmingham, vol. II, Christian Arabic Manuscripts and Additional Syriac Manuscripts (Cambridge: W. Heffer and Sons, 1936) 26-29. 
єт2ємкноүт фрєчш)єм 'nnicoøneq етберноүт фрєцCодсел NMI2HT пІ NAHT 'N(1)ANधMAgT ПI NIC† мПатрІарXнС авва IDANnHC $\bar{\Pi}$ пітрIapXOY

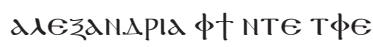
тахрос 2Іxєn песөронос н2аNмн(1) нРОМП нем 2аN

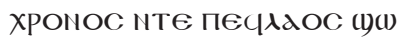
ПI 9EN OY2IPHNH NEM OY метсемнос птоүсшп EYTגХрноүт gEn пINA2†

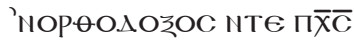
OПOY NEM NIӨMHI NEM NI.AI кеос етоү(удан є†метоү po EथNECOC AMHN ке аріпамеүı мпाєдахістос

$$
\begin{aligned}
& \text { [إن } \\
& \text { السهام المثوقدة } \\
& \text { معزي القلوب } \\
& \text { الرورف الحنون } \\
& \text { العظيم في البطاركة } \\
& \text { انبا يونس بطرير الكارك } \\
& \text { الاسكندرية اله السماء } \\
& \text { يثبته على كرسيه } \\
& \text { سنين كثيرة } \\
& \text { وازمنة ويكون } \\
& \text { شعبه في سلامة وازية } \\
& \text { واطمانية ويكونوا } \\
& \text { ثابتين في الامانة } \\
& \text { الارثنكسية ويكسبهم } \\
& \text { المسيح ابراره } \\
& \text { وصديقية الذين } \\
& \text { فازوا بملكوته امين } \\
& \text { اذكروا الحقير }
\end{aligned}
$$

Fol. 254r

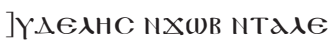

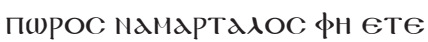
n†м'пуд єөроүмоү十

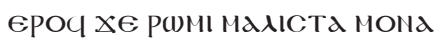
XOC Eप2 п пाMONCTHPION

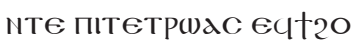
EOYON NIBEN EөNA(W) nянT4 gеn оүагапн nте ф†нтеप

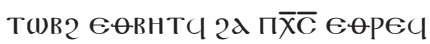
X(1) naq'nneqmoв 'etol) neM nEप()OCT OYO2 nTEप † naq 'noYnal gen пеzоO 'мп†(yeвı) OYO2 OYON

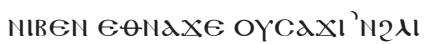

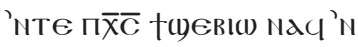
2анмн(1) 'нков

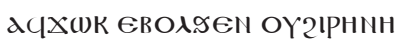
'nTe ф† qEN ПIMONACTH PION 'nte nitetpude $x \in N$ ПІє2ООҮ мПЕ мПІдвюТ дӨюР

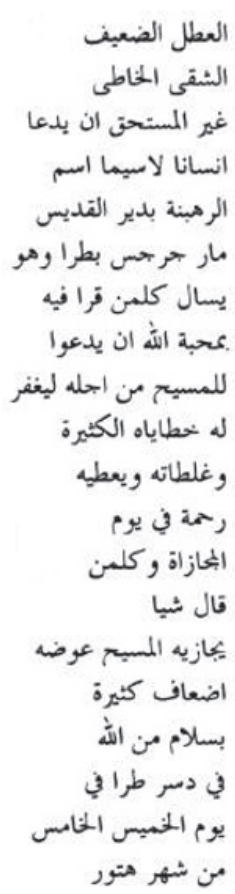


Fol. 254v
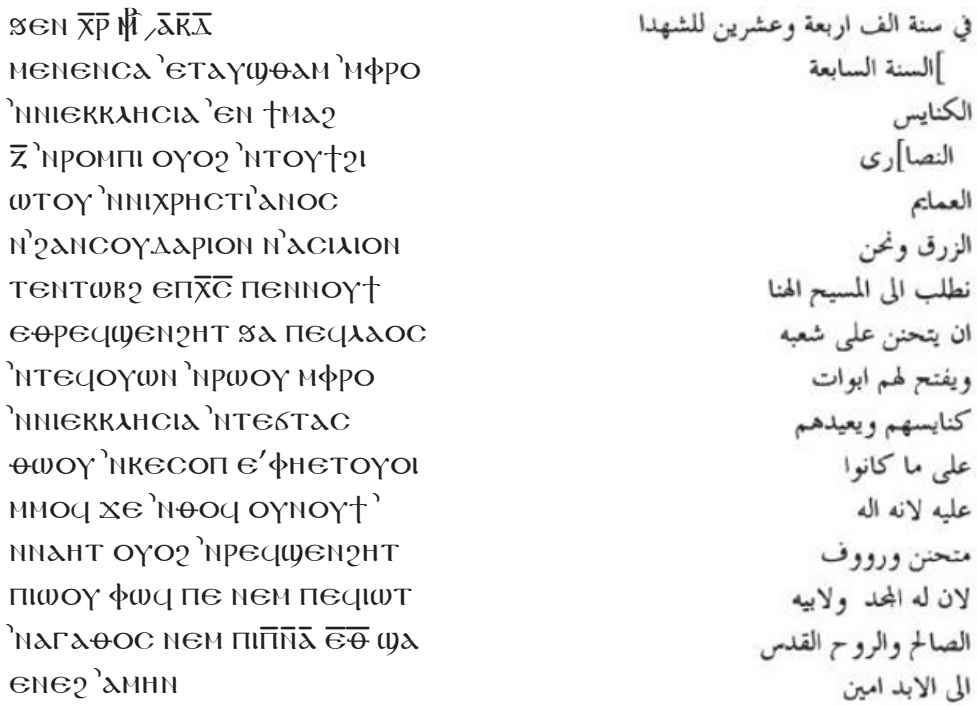

In the name of the Father, the Son and the Holy Spirit, the Holy Trinity consubstansial. This is our God, we the Christians.

This good remembrance holy is this holy book of the consecration ${ }^{4}$ by the virtuous ${ }^{5}$ father, the shepherd entrusted whom Christ established him upon His pure sheep, who bought through His precious blood, in order to pasture them in the fertile garden ${ }^{6}$ and feed their souls with his honest teachings and to make to stand their fallen souls. The teacher, the guide, the straight (fol. 253v) on his paths, the firm stronghold who tread down the afflicted, the quencher of the burning arrows, the comforter of the hearts, the compassionate merciful, the great patriarch Abba John the $80^{\text {th }}$, the patriarch of Alexandria. May God confirm him on his throne for many years and times, while his people is ion peace and solemn, in order that they became firm in the orthodox faith of Christ, so that He (Christ) counts them with the righteous and just who won the beautiful kingdom Amen. Also remember, the humble (fol. 254r) [ ] poor, miserable, the sinner, who is not worthy to be called man moreover monk in the monastery of Tura. He (the scribe) demands, with the charity of God, to everybody who will read it, to pray for him to Christ in order that He forgives

(4) Coptic read differently "This holy book of the consecration is the good remembrance..."

(5) Coptic "most holy."

(6) Coptic "in a fatty place." 
his many sins, and his mistakes and to grant him mercy on the day of reward. And everyone who will say something, Christ reward him nay times. It was finished with the peace of God in the monastery of Tura on the $5^{\text {th }}$ day of the month of Hatur $(254 \mathrm{v})$. In the year 1024 of the Martyrs, (=1307 AD)in the seventh year of the closing down of the churches and the Christians were force to wear the blue turbans. We pray Christ our God to have pity upon his people and to open the gates of the churches and make to return as they were for He is a pitiful and merciful God. Glory be to Him with His Good Father and Holy Spirit forever Amen.

The importance of this manuscript is that it was copied while the churches were closed for seven years however the patriarch John Ibn Qiddis hopped that the churches will be opened and even more churches will be built which necessitated the copying of the book of consecration of the "new" churches.

\section{The psalis}

The psalis are hymns special hymn recited on different occasions. ${ }^{7}$ Ibn Kabar $(+1324 \mathrm{AD})$ in his encyclopaedia "Lamp of Darkness" ${ }^{8}$ mentions that there are new paslis which are not known to everybody and he gave a list of daily psalis. ${ }^{10}$ It is important to mention that the all the psalis mentioned by Ibn Kabar were anonymous. The psalis attributed to an author (such as Sarkis, Nicodemus, Hermina, Christolodus) appeared later. ${ }^{11}$

(7) Yassa 'Aвd Al-Masin, Remarks on the Psalis of the Coptic Church, Bulletin de l'Institut des Études Coptes 1 (1958) 85-100.

(8) For the works of Ibn Kabar, cf. S. KHaliL, L'Encyclopédie liturgique d'Ibn Kabar †1324 et son apologie d'usages coptes, in: H.-J. Feulner, E. VelKovska, R. F. TAFт (eds.), Crosswords of Cultures Studies in Liturgy and Patristics in Honor of Gabriele Winkler (Roma, 2000) 619-655.

(9) This book had never been scholarly published, for the different editions cf. A. WAdi, Abu al-Barakat Ibn Kabar, Misbah al-Zulmah, Studia Orientalia Christiana Collectanea 34 (2001) 243.

(10) L. Villecourt, Les observances Liturgiques et la discipline du Jeûne dans l'Église Copte, Le Muséon 37 (1924) 201-280 and especially 228-229.

(11) Y. Nessim Youssef, Nicodème auteur des psalies, OCP 60 (1994) 625633; IDEM, Recherches d'hymnographie copte: Nicodème et Sarkis, OCP 64 (1998) 383-402; IDEM, The Psalis of Saint John Kame, Bulletin de la Société d'archéologie copte 39 (2000) 257-265; IDEM, Jean évêque d'Assiut, de Manfalut et d'Abu Tig et ses activités littéraires, in: C. CANnuyer (ed.), Études Coptes VIII (Dixième Journée d'études, Lille 14-16 Juin 2001) (Paris-Lille, 2003) (Cahiers de 
As our psalis are anonymous and short (only 13 stanzas for the psali Adam and 8 satanzas for the psali Watos) we may assume that we composed early.

The incipit of these psalis are mentioned by Ibn $\mathrm{Kabar}^{12}$ without giving the complete text. Horner gives the Coptic and the Arabic text. ${ }^{13}$ We consider that an edition of the entire text Coptic Arabic is needed especially that after the first edition many studies had been done.

\title{
Text I
}

\author{
Psali for the Virgin Adam ${ }^{14}$

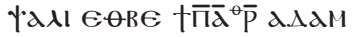 \\ apIBEPI 2APOI NINHCOC APIBEPI \\ каTd TCMH NHCAHAC ПINIC)† \\ мпРОфнтнС

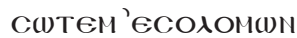

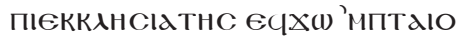 \\ 'mMapla $\dagger \bar{\Pi} \bar{\alpha} \bar{\theta} \bar{p}$ \\ eqmoyt epoc gen mixi) 'nte

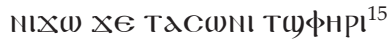 \\ өнєТХнК ЄвО人
}

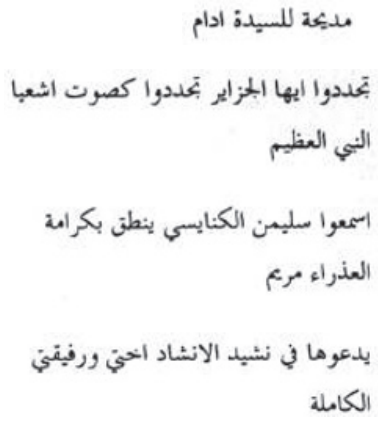

la Bibliothèque Copte, 13) 311-318; IDEM, Recherches d'Hymnographie Copte (2) Hermina et Christodule, in: A. Boud'hors, J. Gascou, D. Vaillancourt (éds.), Études Coptes IX (Paris, 2006) (Cahiers de la Bibliothèque Copte, 14) 381-397.

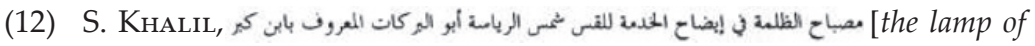
Darkness for the explanation of the Service], vol. 1 (Cairo, 1971) 346.

(13) G. Horner, The Service for the Consecration of a Church and Altar according to the Cooptic Rite, edited with translation from a Coptic and Arabic Manuscript of A.D. 1307 (London, 1902) 391-396 (text), 12-13 (translation) and for a summary of the rite cf. O. H. E. Burmester, The Egyptian or Coptic Church, A detailed description of her liturgical services and the rites and ceremonies observed in the administration of her sacraments (Textes et Documents) (Le Caire: Société d'Archéologie Copte, 1967) 236-250.

(14) The tone to which hymns are sung on Sundays, Mondays and Tuesdays. The name is taken from the first word of the first stanza of the Theotokia of Monday: "Adam was yet sorrowful of heart." Cf. Catalogue of the Coptic and Christian Arabic Mss preserved in the library of the Church of the All-Holy Virgin Mary known as Qasriat Ar-Rihan at Old Cairo (Cairo: Société d'Archéologie Copte, 1973) xii.

(15) Read tydepı cf. W. E. CRum, A Coptic Dictionary (Oxford, 1937) 553a. 


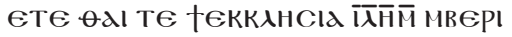

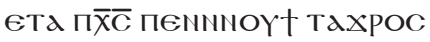
2ıхеn †петра

д еүтдннот нсштп 'нхшх 'млдк2 eүepoywini 'epoc* ete 'a ПІаПОСТОגІкоС нем КүРАגОС пाмде 'MMOYІ ЕтХОР Пихрнсостомос нем васлАос мІпүргос ЄтХор нте

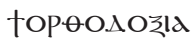
nеM АІоскорос ПІомодІгітне фнетдсо ${ }^{16}$ EяPні мптомос Nג€ON

दтомা 'ершот 'nхе дввд

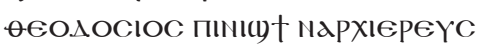
'нте рако† †вакі фнетдсфірі `Єволгіxен пө-

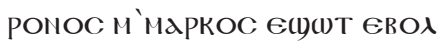

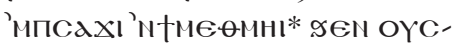
wOYTEN

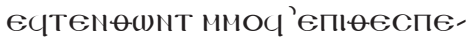
сіоүс паүлос флас 'мп-

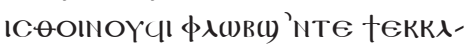
HCld

фнетдстахро 'мпाна2†' 'nте

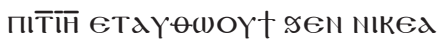

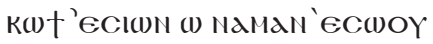
apledal 'ngnhtc caxi gen necПҮРГОС

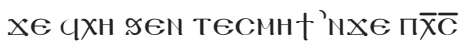
пемnоY 'NnEскIM (уג 'ENE2 ANON 2WN TENTWB2*

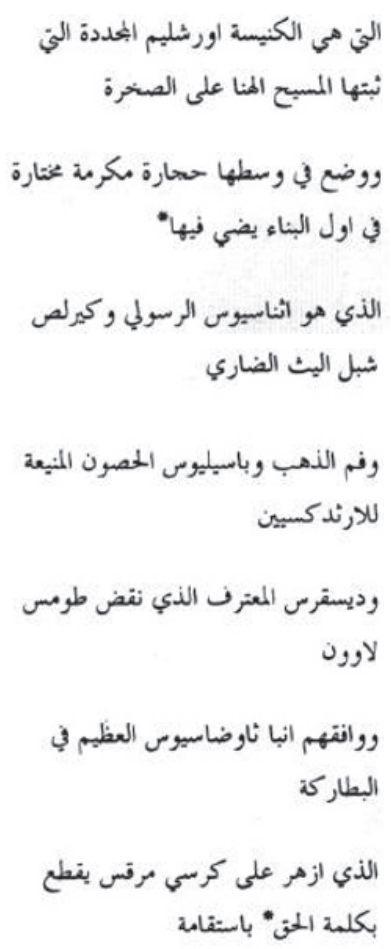

(16) Read 60. 


\section{Translation I}

Renew for me, o islands, renew, according to the voice of the great prophet Isaiah. ${ }^{17}$

Hear to Solomon the ecclesiastes ${ }^{18}$ speaking about the honour of the Virgin:

Calling her in the book Song of Songs: "My sister, my friend (she who is) perfect."

Which is the Church, the new Jerusalem, which Christ our God has established on the rock. ${ }^{19}$

He put in its midst, honoured stones, chosen chief corner stone shining in it,*

Who are Athanasius the Apostolic and Cyril the mighty young of lion.

Chrysostom and Basil the mighty towers of the Orthodoxy.

And Dioscorus the confessor who contradicted the tome of Leo,

Abba Theodosius the great Archpriest of the city Alexandria joined them.

Who flourished on the throne of Mark rightly handling the word of Truth.

He resembled to the holy Paul, the tongue of perfume, the crown of the Church.

He (Theodosius) established the faith of the 318 who assembled in Nicaea

Go round in Sion, o my shepherds, rejoice in it and talk in their towers.

For Christ, our God is its midst, (Church) as a surrounding wall so it will never be shaken ${ }^{20}$ forever.

We also, we pray...

\section{Commentary I}

\section{Stanza 1}

It seems that the scribe in Coptic repeat the second verb while it should be "Listen сштем" the Arabic followed the Coptic.

The Arabic version of the second stanza render пाєкклнсідтнс as "ecclesiastic"

The third stanza resembles to the yearly doxology of the Virgin:

(17) Is. $41: 1$.

(18) G. W. H. Lampe, A Patristic Greek Lexicon (Oxford, 1961) 433b.

(19) Mt. 16:18.

(20) Lit. "It will never move." 


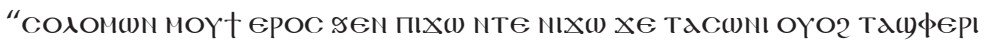
таполІс ммні $\bar{\imath} \overline{\boldsymbol{H}} \bar{\mu} "$

"Solomon has called her, in the Song of Songs: "My sister and my friend, my true city Jerusalem" ${ }^{21}$

This stanza is inspired by the Song of Songs 4:7.

\section{Stanza 3}

the Arabic rendered $\bar{\imath} \bar{\lambda} \bar{M}$ Mrepl "The new Jerusalem" by " الجددة the renewed Jerusalem"

\section{Stanza 4}

While the Coptic has nхwx 'млак2 "corner Stone" the Arabic rendered by البناء the beginning of the building" (i.e. the foundation).

The title of Apostolic for Athanasius is very well attested in Coptic Liturgical books such as in the absolution of the ministers ${ }^{22}$ or the memento sanctorum ${ }^{23}$ as well as in the memento sanctorum of the Psalmo$\mathrm{dia}^{24}$

The title of Cyril occurs in the Ms 23 in fol. Fol. $\overline{\mathrm{c}} \overline{\mathrm{O}} \boldsymbol{\mathrm { r }} \mathrm{r}$ (the actual fol. 3)

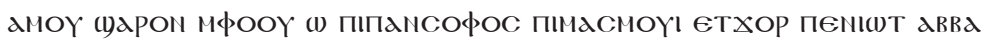

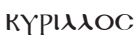

Come to us today, $\mathrm{O}$ all-wise man, the mighty cub, our father Cyril, $^{25}$

And also in the same Ms. Fol. $\overline{\mathrm{c}} \overline{\bar{n}} \overline{\mathrm{z}} \mathrm{v}$

(21) Nahdat 'l-Kanais, пхшм nте †үадмотіа єөоүав нтє мромп мфрн†

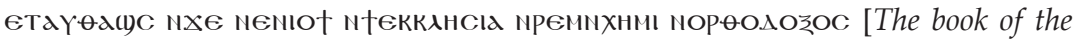
holy Psalmodia of the year accrording to what the Fathers of the Coptic Orthodox Church had established] (Cairo, 1949) 326-327.

(22) We refer to the edition of Abd al-Masih which is considered as the best edition of the Euchologion cf. U. ZANETTI, Esquisse d'une typologie des Euchologes Coptes Bohaïriques, Le Muséon 100 (1987) 407-418. Abd al-

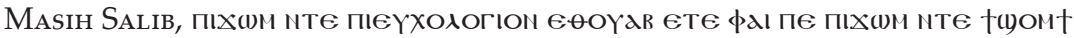

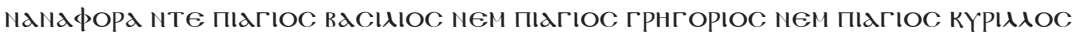
нем 2апкеєүхн єүоүав, [The book of the Holy Euchologion which is the book of the three anaphorae of St. Basil, St. Gregory and St. Cyril and other holy prayers] (Cairo, 1902) 232 (hereafter Euch. 1902).

(23) Euch. 1902, p. 354.

(24) Nahdat '1-KanAIs, пхшм..., 77.

(25) De Lacy O'Leary, The Coptic Theotokia, from Vatican Cod. Copt. XXXVIII Bibli. Nat. Copte 22, 23, 35, 69 aand other Mss. (London: Luzac \&Co, 1923) 17a. 


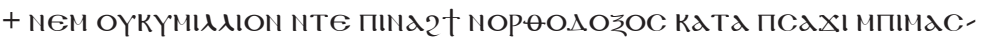

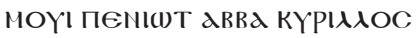

+ and a vessel of orthodox faith according to the word of the young lion, our father Abba Cyril.

\section{Stanza 5}

We find that the two saints mentioned are from Asia Minor and they are remembered especially that they composed two liturgies.

\section{Stanza 6}

The scribe wrote the verb 60 only o this verb is not attested with the preposition єярні ${ }^{26}$ The Arabic rendered with نقض "contradict"

\section{Stanza 7}

The Arabic has ووافقهم meaning "he agreed with them" while it should be rendered "ورافقهم"

The Coptic has "Archpriest" while in Arabic it has "patriarch" as title for Theodosius.

\section{Stanza 8}

The second part of this stanza corresponds to the litany for the patriarch

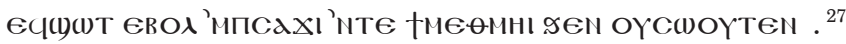

\section{Stanza 9}

The Arabic translator did not understand $\theta € \mathrm{c} п € \mathrm{cloc}^{28}$ which is rare in Coptic liturgical text and translated as the "Instructor" the word Аювс) "crown" was rendered as "pride."

\section{Stanza 10}

It is amazing to find that there are three stanzas (8-10) mainly about Theodosius.

\section{Stanza 11}

This stanza is inspired from

\begin{tabular}{|c|c|}
\hline psalm 48[47]: 12 [10] & Psali \\
\hline 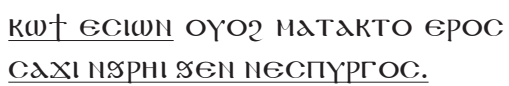 & 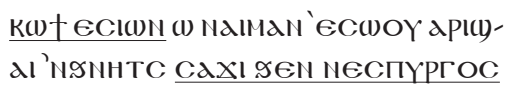 \\
\hline
\end{tabular}

(26) Crum, A Coptic Dictionary..., 752-753.

(27) Euch 1902, p. 283

(28) Lampe, A Patristic Greek Lexicon..., 646. 


\section{Stanza 12}

The author shifts from Sion of the Old Testament to the Church the new Sion.

\section{Stanza 13}

The only few words are mentioned in the last stanza, which means that the author or the scribe assumed that it was known to everybody.

The complete stanza is

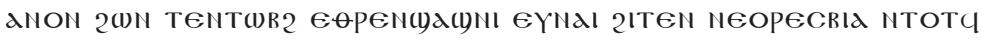
мпімаІршмІ

And we also pray to win mercy, through your intercession, with the Lover of mankind. ${ }^{29}$

\section{Text II}

In Arabic

And if it was a Watos ${ }^{30}$ day, they say this psali

$$
\text { مان اتفق ان يكون يوم الواطس فتقال هذه المديكة }
$$

Yadi 'нхос ватос

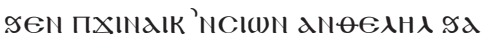

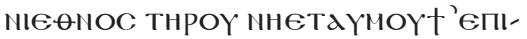

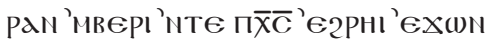
оүгар Cenacormi an Xe мфрн† 'ноYскүHн gen 2aHMa 'HaגOג

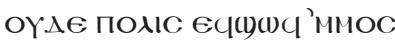

alda eүнamoYt epo хе фман(y)п 'мфнетбоси нем †скүнн өнетоүмоүt'єерос $x \in$ xe (sic) өнеөоүав

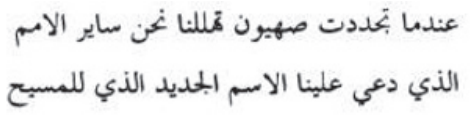

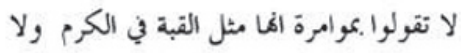

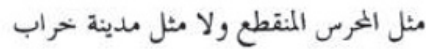

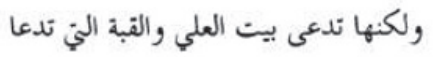

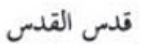
nTE NHE:OYAB нем пाпара.AICOC 'нте* ф† фнетасер(у)рп 'нтохі 'ммос мпा(у) 'nрестаняо 'нте пाг $\bar{\Gamma}^{p} \overline{\mathrm{C}}^{\prime}$

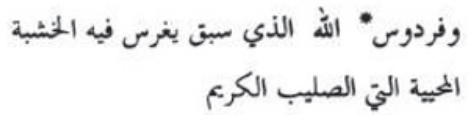

(29) Nahdat '1-KanAIs, пхшм..., 102-103.

(30) The tone to which hymns are sung on Wednesdays, Thursdays, Fridays and Saturdays. the name is taken from the first stanza of the Theotokia for Thursday: "The Bush which Moses saw in the desert." 


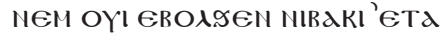

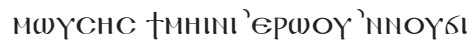

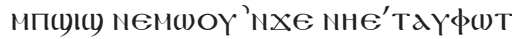

2גPEOY

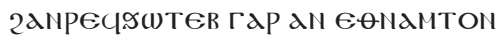

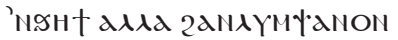

еттдіноүт nе 'nTe nipeqбро

MAPTYPOC

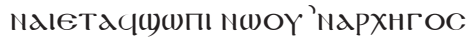

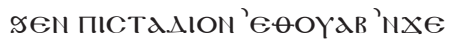

фн'єөоүав стефанос* пирєцбіх-

лом gEN OYMEөMH

aсгісеn† гар мmо 'nхе пенnнв

$\overline{\mathrm{i}} \overline{\mathrm{C}} \Pi \overline{\mathrm{X}} \overline{\mathrm{C}}$
او واحدة من المدن التي اشار همم موسى ان

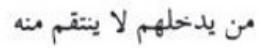

ليس هم قتلى يسنريحون فيك لكنهم اجساد

مكرمة للشهدا الغالبين

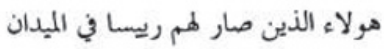

المقدس اعتي استافانس" الغالب بالحقيقة

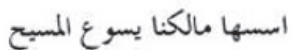

\section{Transalation II}

At the dedication of Sion, we, all the nations, rejoiced, who were called by the new name of Christ

For they will neither consider it as a tent ${ }^{31}$ in the vineyard nor (as) a deserted city.

But it will be called the dwelling of the Most High and the tabernacle which is called the holy of Holies.

And the Paradise of God wherein he preceded to plant the lifegiver wood of the Cross

And one of the cities which Moses indicated that those who take refuge to them, would be revenged.

No murders will rest in you (o Church) but honoured relics of the winner martyrs.

Those whose leader in the holy stadium is saint Stephen the truly bearer of the crown

For our Lord Jesus Christ established it (the church)

\section{Commentary II}

\section{Stanza 1}

the Coptic used the noun $\operatorname{dIK}^{32}$ as verb, with the verbal prefix $x \mathrm{In}$ to form a noun. The Arabic rendered differently

"When Sion was renewed, we, all the nation who were called with the new name of Jesus, rejoice.

(31) Or "a cottage"

(32) CRum, A Coptic Dictionary..., 3 a. 


\section{Stanza 2}

The stanza started with an analogy inspired by Isaiah 1:8 and Proverbs 25:28. It is important to mention that the book of Proverbs in Bohairic did entirely not survive. ${ }^{33}$

The Arabic rendered the verb corinl with تقولوابموامرة do not say with conspiracy"

We prefer to translate the Loan Greek word скүнн with tent while in Arabic it is rendered as القبة "the dome"

\section{Stanza 3}

The first part of the stanza is inspired by many biblical texts among them Ps 91: 9

The second part is a direct quotation from two stanzas of the Sunday's Theotokia

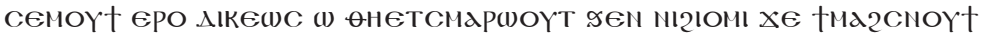
NCKHNH

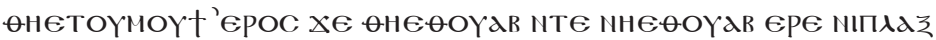
NSHTC

You are truly called, O blessed, among the women, the second Tabernacle

Which is called the Holy of Holies, wherein are the tablets. ${ }^{34}$

\section{Stanza 4}

The stanza is inspired by Apocalypse 2:7.

الصلب الكرع The Arabic adds to the translation of the "Precious Cross

\section{Stanza 5}

The text is inspired by Number 35:6,11, etc about the city of refuge.

The Arabic replace nem g "and" gy "Or"

\section{Stanza 6}

The author of this stanza assumes that the church will be built over the relics of the martyrs As in the Apocalypse 6:9. "And when he had opened the fifth seal, I saw under the altar the souls of them that were slain for the word of God, and for the testimony"

(33) S. WAgner, The Coptic Book of Job and Leiden Or. 14.544: An inquiry into its Textual History and its place with the Book of the Proverbs, Saint Shenouda Coptic Quaterly 1/3 (April 2005) 3-23.

(34) Nahdat 'l-Kanais, пхшм..., 101. 


\section{Stanza 7}

While in Coptic we have the bearer of Crown пıрецбıхлом - the Araالغالب bic version rendered with the victorious

\section{Stanza 8}

In this stanza, the Arabic differs from the Coptic. The Arabic should be translated "Jesus Christ our King established it"

\section{Conclusion}

Despite that the book of the consecration of the Church was published many years ago, ${ }^{35}$ several points should be observed:

1. The date of the Manuscript: The manuscript was copied while the Churches were closed for seven years. This could reflect the hope that the patriarch John Ibn Qiddis had. Not only by ordering the copying of the Manuscript of the consecration of the Churches but also the patriarch consecrates the Myron in the year 1305. ${ }^{36}$ It is known that the Myron is used for the sanctification of the Water of the Baptistery, the unction of the new baptized, the consecration of the new churches, the consecration of the altars, the consecration of the portable altars, the consecration of the liturgical vessels, the consecration of the icons and the unction of the kings. ${ }^{37}$ All these activities need a certain freedom which was unavailable in his time.

2. The psalis were composed in Coptic and later were translated in Arabic hence we find some differences

3 . The author had a very good knowledge of the liturgical texts.

4. We can find a special veneration for Theodosius, in the psali Adam that surpass the other saints.

5. The author used free quotations from the Bible and especially from the psalms, Isaiah, and the book of revelation which are read during the ceremony of consecration the Church.

6. Most of the Loan Greek words used in these texts are known from other liturgical texts, which could be an indication that the Greek was not used as a spoken language in the time of the composition of the psalis.

(35) See above.

(36) A. Van Lantschoot, Le manuscrit Vatican Copte 44 et le Livre du Chême ms Paris arabe 100, Le Muséon 45 (1932) 181-234 especially 208-209, 230-231.

(37) Cf. Burmester, The Egyptian or Coptic Church..., see index. 
7. The first psali from the praising of the Virgin while talking about the Church., The reasoning behind is easy to grasp: On the one hand, in the theotokia of Sunday, (as in the Marian homilies of Severus) the tabernacle symbolized the Virgin Mary, ${ }^{38}$ on the other hand The tabernacle is the pre-figuration of Church of the New Testament, hence the Virgin Mary is the symbol of the Church. ${ }^{39}$

8. The key-word in psali is "renew", it is known that under the Islamic law the building of a new church was forbidden ${ }^{40}$

\section{SUMMARY}

Since Horner's publication no further studies had been done. In this article we will study several aspects of these psalis such as theology, liturgy and history.

(38) Y. Nessim Youssef, The Coptic Marian homilies of Severus of Antioch, Bulletin de la Société d'Archéologie Copte 43 (2004) 127-140.

(39) For a detailed study of this theme cf. C. VolLert, Mary and the Chruch, in: J. CARol (ed.), Mariology (Milwaukee: The Bruce publishing company, 1957) 550-595.

(40) A. FATTAL, Le Statut légal des non-musulmans en pays de l'islam (Beirut, 1958). 